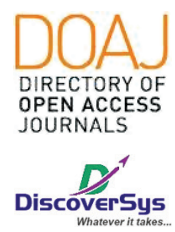

Published by DiscoverSys

\title{
Hubungan perilaku penggunaan gadget terhadap miopia pada anak sekolah dasar kelas 6 di Kota Denpasar
}

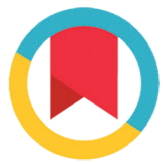

CrossMark

\author{
Gede Anantha Restu Permana, ${ }^{1{ }^{*}}$ Komang Ayu Kartika Sari, ${ }^{2}$ Putu Aryani ${ }^{2}$
}

\section{ABSTRACT}

Introduction: Myopia is a state of vision in which light fall in front of retina that causes blurred appearance of distant objects. The prevalence of myopia in Indonesia reaches $25 \%$ in adults and $10-12 \%$ in children. Method: This study aimed to identify the relationship of gadget usage behavior and myopia on sixth grade of elementary school children in Denpasar. This study was conducted by analytical method with crosssectional design. Gadget usage behavior included position, visibility, and duration of gadget usage which were measured by questionnaire. Myopia was measured by snellen chart. Samples of this study were 100 sixth grade children of Saraswati 2 Elementary School in Denpasar which were selected by simple random sampling technique.
Result: Results of this study showed that there was no relationship between position of gadget usage and myopia ( $p$ value $=0.059$ ). There was a relationship between eye to gadget distance and myopia ( $p$ value $=0.000$ ). Duration of gadget usage per day was not related to myopia with ( $p$ value $=0.490$ ).

Conclusion: The results of this study are useful for early prevention to children about risk factors of the gadget usage behavior towards myopia. Researchers suggest to other researchers to examine using other research methods and besides examining factors related to myopia such as genes, light intensity, and outdoor or indoor activities.

Keywords: myopia, gadget, gadget usage behavior.

Cite This Article: Permana, G.A.R., Sari, K.A.K., Aryani, P. 2020. Hubungan perilaku penggunaan gadget terhadap miopia pada anak sekolah dasar kelas 6 di Kota Denpasar. Intisari Sains Medis 11(2): 763-768. D0I: 10.15562/ism.v11i2.694

\section{ABSTRAK}

Latar Belakang: Miopia merupakan keadaan penglihatan dimana cahaya jatuh di depan retina yang menyebabkan objek jauh terlihat kabur. Prevalensi miopia di Indonesia mencapai $25 \%$ pada orang dewasa dan 10-12\% pada anak-anak. Penelitian ini bertujuan untuk mengidentifikasi dan menguraikan hubungan perilaku penggunaan gadget terhadap miopia pada anak sekolah dasar kelas 6 di Denpasar. Metode: Penelitian ini dilakukan dengan metode analitik menggunakan desain potong-lintang. Perilaku penggunaan gadget meliputi posisi, jarak pandang, dan durasi penggunaan gadget dinilai dengan menggunkan kuisioner. Status miopia sendiri diukur menggunakan snellen chart. Sampel penelitian adalah 100 orang anak kelas 6 di SD Saraswati 2 Denpasar yang dipilih melalui teknik simple random sampling.

Fakultas Kedokteran Universitas Udayana

${ }^{2}$ Bagian IImu Kedokteran Komunitas/llmu Kedokteran Pencegahan, Fakultas Kedokteran Universitas Udayana

${ }^{*}$ Correspondence to:

Gede Anantha Restu Permana, Program Studi Pendidikan Dokter, Fakultas Kedokteran Universitas Udayana

aikanantha@gmail.com

Diterima: $15-01-2020$

Disetujui: 07-07-2020

Diterbitkan: 01-08-2020

Kata kunci: miopia, gadget, perilaku penggunaan gadget.

\section{PENDAHULUAN}

Miopia adalah kelainan refraksi dimana cahaya jatuh di depan retina sehingga menyebabkan objek yang letaknya jauh terlihat kabur. ${ }^{1}$ Angka prevalensi miopia sangat tinggi dan merupakan salah
Hasil: Hasil penelitian ini menunjukkan bahwa tidak terdapat hubungan antara posisi penggunaan gadget terhadap miopia dengan nilai $p=0,059$. Terdapat hubungan antara jarak pandang penggunaan gadget terhadap miopia dengan nilai $p=0,000$. Durasi penggunaan gadget perhari tidak berhubungan terhadap miopia dengan nilai $p=0,490$.

Simpulan: Hasil dari penelitian ini bermanfaat untuk melakukan pencegahan sejak dini kepada anak-anak tentang faktor risiko dari perilaku penggunaan gadget terhadap miopia. Peneliti menyarankan agar penelitian selanjutnya dilakukan dengan menggunakan metode penelitian lain serta meneliti pula faktor yang berhubungan dengan miopia seperti gen, intensitas cahaya, aktivitas luar ruangan dan dalam ruangan.

Cite Pasal Ini: Permana, G.A.R., Sari, K.A.K., Aryani, P. 2020. Hubungan perilaku penggunaan gadget terhadap miopia pada anak sekolah dasar kelas 6 di Kota Denpasar. Intisari Sains Medis 11(2): 763-768. D0l: 10.15562/ism.v11i2.694 satu dari lima besar penyebab kebutaan di seluruh dunia. Prevalensi myopia menurut data World Health Organization (WHO) tahun 2010 diperkirakan mencapai 27\% (1893 juta). Prevalensi miopia paling tinggi terdapat di Asia timur seperti Cina, Jepang, dan Korea, setelah itu diikuti oleh Singapura 
yang memiliki prevalensi sekitar 50\%. Australia, Eropa, Amerika Utara dan Amerika Selatan memiliki prevalensi yang lebih rendah dibandingkan dengan negara-negara di Asia. ${ }^{2}$ Sebesar 20\% anakanak sekolah dasar dan $80 \%$ orang dewasa di Asia Tenggara mengalami miopia. Angka prevalensi miopia di Indonesia mencapai $25 \%$ pada orang dewasa dan $10-12 \%$ pada anak-anak. ${ }^{3}$

Penyebab miopia bersifat multifaktorial dan dapat bersifat internal atau eksternal. ${ }^{4}$ Faktor internal meliputi genetik, riwayat keluarga, panjang bola mata, usia, jenis kelamin dan etnik. Faktor genetik atau faktor keturunan merupakan faktor yang berasal dari keluarga, dimana lokalisasi kromosom dan karakteristik dari molekul gen dapat berpengaruh terhadap terjadinya myopia. ${ }^{5}$ Faktor eksternal berhubungan dengan banyak atau lamanya aktivitas luar ruangan atau pola hidup sehari-hari seperti pencahayaan, pendidikan, dan aktivitas jarak dekat, contohnya membaca dan bermain gadget. ${ }^{6}$

Seiring perkembangan zaman, gadget kini juga mulai digunakan oleh kalangan anak usia sekolah dasar. Penggunaan telepon seluler meningkat dalam jumlah yang tinggi di seluruh dunia pada tahun 2009 yaitu mencapai lebih dari 4,3 miliar. Data Kementerian Komunikasi dan Informasi tahun 2015 menyatakan bahwa di Indonesia sekitar 55 juta orang menggunakan smartphone dan Indonesia termasuk dalam 5 besar angka penggunaan smartphone tertinggi di dunia. Pengenalan gadget pada kalangan usia anak sekolah dasar masih terlalu dini, dimana pada umur tersebut anak-anak lebih disarankan untuk melakukan aktivitas/permainan fisik, atau bermain secara langsung dalam kelompok. ${ }^{7,8}$

Salah satu dampak negatif dari penggunaan gadget yaitu terkena penyakit miopia. Penelitian yang dilakukan di Sekolah Dasar Negeri (SDN) Majalaya 2 pada siswa kelas 3 hingga 5 SD dengan 44 responden mendapatkan hasil bahwa 75\% dari responden yang bermain gadget dengan durasi lebih dari 2 jam sehari cenderung mengalami penurunan visus. Penelitian tersebut menunjukkan responden yang bermain video game selama lebih dari 2 jam sehari memiliki peluang 3,1 kali lebih besar untuk mengalami penurunan ketajaman penglihatan dibanding siswa yang bermain game selama kurang dari 2 jam sehari., ${ }^{910}$ Contoh penggunaan gadget yang tidak benar antara lain frekuensi penggunaannya yang eksesif, posisi yang tidak sesuai, dan tingkat pencahayaan yang kurang baik akan menyebabkan kelemahan refraksi mata atau miopia. ${ }^{11}$

Kecenderungan anak-anak sekolah dasar dalam menggunakan gadget membuat penulis tertarik untuk melakukan penelitian tentang hubungan perilaku penggunaan gadget terhadap miopia. Semakin dini mata seseorang dikenakan pancaran sinar secara langsung, maka semakin besar potensi terkena miopia karena organ mata sedang berkembang pada awal-awal tahun kehidupan. ${ }^{12}$ Melihat di masa yang akan datang kemungkinan faktor penggunaan gadget lebih berpengaruh, maka pada proposal ini penulis akan membahas hubungan perilaku penggunaan gadget terhadap miopia pada anak sekolah dasar kelas 6 di Denpasar.

\section{BAHAN DAN METODE}

Penelitian ini merupakan penelitian analitik dengan uji korelasional dengan desain penelitian studi potong-lintang (cross-sectional) untuk mengetahui hubungan perilaku dalam menggunakan gadget dengan kejadian miopia pada anak. Sampel pada penelitin ini adalah 100 siswa kelas 6 SD Saraswati 2 Denpasar, Dangin Puri Kangin, Kecamatan Denpasar Utara, Kota Denpasar yang dipilih melalui metode uji hipotesis terhadap 2 proporsi. Cara pengambilan sampel dalam penelitian ini menggunakan teknik simple random sampling. Penelitian dilakukan pada Agustus hingga September tahun 2019.

Penelitian dilakukan dengan menggunakan kuisioner yang berisi faktor risiko miopia (posisi bermain gadget, intensitas cahaya gadget, jarak dengan gadget, dan lamanya bermain gadget). Peneliti juga menggunakan snellen chart untuk mengukur visus siswa dan meteran untuk mengukur jarak pandang siswa terhadap gadget.

Analisis univariat dilakukan untuk mengetahui gambaran distribusi frekuensi variabel independen (posisi bermain gadget, intensitas cahaya dalam menggunakan gadget, frekuensi bermain gadget, dan jarak dengan gadget) dan variabel dependen (miopia). Analisis bivariat dilakukan untuk melihat hubungan antar variabel independen dan variabel dependen dengan menggunakan uji chi-square $\left(\mathrm{x}^{2}\right)$ untuk memeriksa lebih lanjut hubungan antara dua variabel dengan tingkat signifikansi tertentu. Hipotesis nol (Ho) penelitian ini menyatakan bahwa tidak ada hubungan yang signifikan antara perilaku penggunaan gadget terhadap miopia pada anak sekolah dasar kelas 6 di Denpasar. Hipotesis alternatif $(\mathrm{Ha})$ penelitian ini menyatakan bahwa terdapat hubungan yang signifikan antara perilaku penggunaan gadget terhadap miopia pada anak sekolah dasar kelas 6 di Denpasar. Nilai $\mathrm{p}<0,05$ dianggap signifikan secara statistik. Uji normalitas dilakukan dengan uji Kolmogorov Smirnov. Data yang telah terkumpul kemudian dikategorikan sesuai tujuan dan ditabulasi dalam bentuk tabel untuk setiap variabel sesuai dengan tujuan penelitian. 
Penelitian ini telah mendapat persetujuan dari Komisi Etik Penelitian Kesehatan Fakultas Kedokteran Universitas Udayana/Rumah Sakit Umum Pusat (RSUP) Sanglah Denpasar, Bali.

\section{HASIL}

Responden pada penelitian ini adalah anak-anak sekolah dasar kelas 6 di SD Saraswati 2 Denpasar dengan jumlah sampel 100 orang anak yang telah memenuhi kriteria inklusi dan eksklusi dari penelitian. Mayoritas responden berjenis kelamin perempuan yaitu berjumlah 51 orang (51\%) sementara laki-laki berjumlah 49 orang (49\%). Umur anak yang paling banyak adalah umur 11 tahun sebanyak 84 orang $(84 \%)$, umur 10 tahun berjumlah 3 orang

Tabel 1 Distribusi Frekuensi Karakteristik Responden Berdasarkan Jenis Kelamin, Umur, Jumlah Jenis Gadget yang Digunakan, Refraksi Mata, dan Perilaku Penggunaan Gadget

\begin{tabular}{|c|c|c|c|}
\hline No & Karakteristik Responden & Jumlah & $\%$ \\
\hline \multirow[t]{4}{*}{1} & Jenis Kelamin & & \\
\hline & Laki-laki & 49 & 49 \\
\hline & Perempuan & 51 & 51 \\
\hline & Total & 100 & 100 \\
\hline \multirow[t]{5}{*}{2} & Umur (Tahun) & & \\
\hline & 10 & 3 & 3 \\
\hline & 11 & 84 & 84 \\
\hline & 12 & 13 & 13 \\
\hline & Total & 100 & 100 \\
\hline \multirow[t]{4}{*}{3} & Jumlah Jenis Gadget Yang Digunakan & & \\
\hline & $<2$ & 87 & 87 \\
\hline & $>2$ & 13 & 13 \\
\hline & Total & 100 & 100 \\
\hline \multirow[t]{4}{*}{4} & Refraksi Mata & & \\
\hline & Normal & 59 & 59 \\
\hline & Miopia & 41 & 41 \\
\hline & Total & 100 & 100 \\
\hline \multirow[t]{4}{*}{5} & Posisi Menggunakan Gadget & & \\
\hline & Duduk & 69 & 69 \\
\hline & Tiduran/Telungkup & 31 & 31 \\
\hline & Total & 100 & 100 \\
\hline \multirow[t]{4}{*}{6} & Jarak Pandang Penggunaan Gadget & & \\
\hline & $>30 \mathrm{~cm}$ & 42 & 42 \\
\hline & $<30 \mathrm{~cm}$ & 58 & 58 \\
\hline & Total & 100 & 100 \\
\hline \multirow[t]{4}{*}{7} & Frekuensi Penggunaan Gadget Perhari & & \\
\hline & $<2 \mathrm{jam}$ & 23 & 23 \\
\hline & $>2$ jam & 77 & 77 \\
\hline & Total & 100 & 100 \\
\hline
\end{tabular}

(3\%) dan umur 12 tahun berjumlah 13 orang (13\%). Jenis gadget yang digunakan dikategorikan menjadi 2 yaitu untuk anak yang menggunakan $<2$ jenis gadget dan anak yang menggunakan $>2$ jenis gadget. Anak yang menggunakan $<2$ jenis gadget berjumlah 87 orang $(87 \%)$ dan anak yang menggunakan $>2$ jenis gadget berjumlah 13 orang (13\%). Hasil pengukuran snellen chart mendapatkan anak yang mengalami miopia adalah sejumlah 41 orang $(41 \%)$ dan anak dengan mata normal sejumlah 59 orang (59\%) (Tabel 1).

Lebih banyak anak yang menggunakan gadget dengan posisi duduk yaitu sejumlah 69 orang (69\%). Lebih banyak anak menggunakan gadget dengan jarak pandang $<30 \mathrm{~cm}$ sejumlah 58 orang (58\%). Anak lebih banyak menggunakan gadget dengan durasi $>2$ jam perhari yaitu sejumlah 77 orang (77\%) (Tabel 2).

Proporsi anak dengan kategori posisi penggunaan gadget dengan posisi tiduran atau telungkup dan mempunyai penglihatan yang miopia cenderung lebih tinggi yaitu 54,8\%. Proporsi anak dengan kategori posisi penggunaan gadget dengan posisi duduk dan mempunyai penglihatan yang miopia yaitu sebesar $34,8 \%$ dengan nilai $p=0,059$. Hal ini berarti tidak terdapat hubungan antara posisi penggunaan gadget terhadap miopia. Nilai rasio prevalensi yang didapatkan yaitu 1,577 artinya anak yang menggunakan gadget pada posisi tiduran atau telungkup memiliki probabilitias mengalami miopia 1,577 kali lebih tinggi dibandingkan anak yang menggunakan gadget pada posisi duduk (Tabel 2).

Proporsi anak dengan jarak pandang penggunaan gadget $<30 \mathrm{~cm}$ dan dengan penglihatan yang miopia didapatkan lebih banyak yaitu $60,3 \%$. Proporsi anak dengan jarak pandang penggunaan gadget $>30 \mathrm{~cm}$ dengan penglihatan yang miopia yaitu sebesar $14,3 \%$. Uji chi square mendapatkan nilai $\mathrm{p}=0,000$. Hal ini berarti terdapat hubungan antara jarak pandang penggunaan gadget terhadap miopia. Nilai rasio prevalensi yang didapatkan yaitu 4,224 artinya anak dengan jarak pandang penggunaan gadget $<30 \mathrm{~cm}$ memiliki probabilitas anak dengan penglihatan miopia 4,224 kali lebih tinggi dibandingkan anak dengan jarak pandang penggunaan gadget $>30 \mathrm{~cm}$ (Tabel 2).

Proporsi anak dengan frekuensi penggunaan gadget $>2$ jam per hari dengan penglihatan miopia cenderung lebih banyak yaitu 42,9\%. Proporsi anak dengan frekuensi penggunaan gadget $<2$ jam per hari dengan penglihatan miopia yaitu sebesar $34,8 \%$. Hasil uji statistik chi square diperoleh nilai $\mathrm{p}=0,490$. Hal ini berarti tidak terdapat hubungan antara frekuensi penggunaan gadget terhadap miopia. Nilai rasio prevalensi yang didapatkan yaitu 1,232 artinya anak dengan frekuensi penggunaan 
Tabel 2 Hubungan Posisi, Jarak Pandang dan Durasi Penggunaan Gadget Terhadap Miopia pada Anak Sekolah Dasar Kelas 6 di SD Saraswati 2 Denpasar

\begin{tabular}{|c|c|c|c|c|c|c|c|c|c|}
\hline \multirow[b]{2}{*}{ Variabel } & \multicolumn{2}{|c|}{ Miopia } & \multicolumn{2}{|c|}{ Normal } & \multirow[b]{2}{*}{ Total } & \multirow[b]{2}{*}{$\%$} & \multirow[b]{2}{*}{ Nilai p } & \multirow[b]{2}{*}{ Rasio Prevalensi } & \multirow[b]{2}{*}{$95 \% \mathrm{Cl}$} \\
\hline & $\mathbf{N}$ & $\%$ & $\mathbf{N}$ & $\%$ & & & & & \\
\hline \multicolumn{10}{|l|}{ Posisi } \\
\hline Tiduran/Telungkup & 17 & 54,8 & 14 & 45,2 & 31 & 100 & & 1,577 & $1,001-2,483$ \\
\hline Duduk & 24 & 34,8 & 45 & 65,2 & 69 & 100 & 0,059 & & \\
\hline Total & 41 & 41 & 59 & 59 & 100 & 100 & & & \\
\hline \multicolumn{10}{|l|}{ Jarak Pandang } \\
\hline$<30 \mathrm{~cm}$ & 35 & 60,3 & 23 & 39,7 & 58 & 100 & & 4,224 & $1,957-9,120$ \\
\hline$>30 \mathrm{~cm}$ & 6 & 14,3 & 36 & 85,7 & 42 & 100 & 0,000 & & \\
\hline Total & 41 & 41 & 59 & 59 & 100 & 100 & & & \\
\hline \multicolumn{10}{|l|}{ Durasi } \\
\hline$>2 \mathrm{jam}$ & 33 & 42,9 & 44 & 57,1 & 77 & 100 & & 1,232 & $0,665-2,282$ \\
\hline$<2 \mathrm{jam}$ & 8 & 34,8 & 15 & 65,2 & 23 & 100 & 0,490 & & \\
\hline Total & 41 & 41 & 59 & 59 & 100 & 100 & & & \\
\hline
\end{tabular}

gadget $>2$ jam per hari memiliki probabilitas mengalami miopia 1,232 kali lebih tinggi dibandingkan anak dengan frekuensi penggunaan gadget $<2$ jam perhari (Tabel 2).

\section{PEMBAHASAN}

Anak yang menggunakan gadget dengan posisi duduk didapatkan sebesar 34,8\% dengan miopia, sedangkan anak dengan posisi tiduran atau telungkup didapatkan sebesar $54,8 \%$ dengan miopia. Hasil uji chi square didapatkan tidak adanya hubungan antara posisi penggunaan gadget terhadap miopia $(\mathrm{p}=0,059$ atau $\mathrm{p}>0,05)$. Hal ini sesuai dengan penelitian sebelumnya yang menyatakan bahwa tidak terdapat hubungan antara posisi penggunaan gadget dengan miopia dengan nilai $\mathrm{p}=0,479 .{ }^{13}$ Penelitian yang dilakukan pada tahun 2013 juga menunjukkan tidak adanya hubungan yang bermakna untuk seluruh parameter aktivitas jarak dekat dengan miopia. ${ }^{14}$ Hasil penelitian ini tidak sejalan dengan hasil penelitian lain yang menunjukan adanya hubungan antara posisi penggunaan gadget dengan penurunan tajam penglihatan pada anak usia 6-12 tahun. ${ }^{11}$

Tingginya proporsi anak yang menggunakan gadget dengan posisi tiduran atau telungkup yang menderita miopia disebabkan karena menggunakan gadget dengan posisi tidur atau telungkup membuat mata tidak bisa berelaksasi karena otot mata perlu menarik bola mata kearah bawah secara terus menerus serta mengikuti posisi objek sehingga mata akan berakomodasi secara berlebih. Mata yang berakomodasi berlebihan dalam periode yang lama akan lebih mudah mengalami penurunan kemampuan mata melihat jauh. ${ }^{15}$ Proporsi anak yang menggunakan gadget dengan posisi duduk yang menderita myopia adalah sebesar $34,8 \%$. Hal ini dipengaruhi oleh beberapa faktor lainnya seperti faktor frekuensi penggunaan gadget dan jarak pandang mata ke gadget. Hal ini juga dapat dilihat dari hubungan korelasi yang didapatkan bahwa tidak adanya hubungan posisi penggunaan gadget terhadap miopia, hal ini menunjukan bahwa miopia disebabkan oleh beberapa faktor risiko dari miopia dan tidak selalu disebabkan oleh posisi penggunaan gadget yang berisiko (tidur dan telungkup).

Anak yang menggunakan gadget dengan jarak pandang $>30 \mathrm{~cm}$ didapatkan sebesar $14,3 \%$ yang menderita miopia. Anak yang menggunakan gadget dengan jarak pandang $<30 \mathrm{~cm}$ didapatkan sebesar 60,3\% menderita miopia. Hasil uji chi square menunjukkan adanya hubungan antara jarak pandang penggunaan gadget terhadap miopia dengan nilai $\mathrm{p}=0,000(\mathrm{p}<0,05)$. Hal ini sesuai dengan penelitian sebelumnya yang menyatakan bahwa terdapat hubungan antara jarak penggunaan gadget terhadap miopia dengan nilai $\mathrm{p}=0,031 \cdot{ }^{13}$ Penelitian yang dilakukan pada tahun 2017 mendapatkan hasil bahwa terdapatnya hubungan antara jarak menonton televisi dengan miopia dengan nilai $\mathrm{p}=0,002 \cdot{ }^{16}$ Penelitian tersebut mendapatkan sebesar $85 \%$ siswa yang menonton televisi dalam jarak dekat mengalami rabun penglihatan. Hal ini menunjukkan bahwa gadget visual dan kebiasaan menggunakaan gadget bisa dikatakan menjadi faktor utama yang terkait dengan miopia.

Faktor gaya hidup seperti aktivitas melihat dekat yang terlalu sering seperti melihat layar komputer, bermain video game, membaca buku dan menonton televisi dapat menyebabkan melemahnya otot siliaris mata yang mengakibatkan terganggunya 
kemampuan mata untuk melihat jauh (miopia). Hal ini dengan mudah dilakukan oleh anak karena tingginya akses anak terhadap aktivitas media visual pada zaman sekarang. Tingginya aktivitas media visual ini apabila tidak dibarengi dengan pengawasan yang baik terhadap perilaku penggunaan gadget yang buruk seperti jarak pandang anak yang terlalu dekat serta kurangnya jeda istirahat pada penggunaan dapat meningkatkan kejadian miopia. ${ }^{17}$

Anak yang menggunakan gadget dengan frekuensi $<2$ jam per hari didapatkan sebesar $34,8 \%$ menderita miopia. Anak yang menggunakan gadget dengan frekuensi $>2$ jam per hari didapatkan $42,9 \%$ menderita miopia. Hasil uji chi square mendapatkan tidak adanya hubungan antara frekuensi penggunaan gadget terhadap miopia dengan nilai $p=0,490 \quad(p>0,05)$. Hal ini sejalan dengan penelitian terdahulu yang menyatakan bahwa tidak terdapatnya hubungan antara lama penggunaan gadget terhadap ketajaman pengliha$\tan (\mathrm{p}=0,815) \cdot{ }^{18}$ Hasil tersebut juga sejalan dengan hasil penelitian yang dilakukan pada tahun 2013 dimana dari hasil penelitian tersebut didapatkan bahwa tidak terdapat hubungan antara frekuensi penggunaan laptop, handphone, dan video game terhadap miopia $(\mathrm{p}=0,940) \cdot{ }^{14}$ Hasil penelitian ini menunjukkan bahwa semakin tinggi aktivitas yang melibatkan pandangan dekat maka akan semakin tinggi pula pertambahan derajat miopianya. Hal ini sesuai dengan teori yang menyatakan bahwa kebiasaan membaca atau menggunakan gadget dengan waktu yang lama dapat menyebabkan tonus siliaris menjadi tinggi sehingga lensa akan berubah menjadi lebih cembung sehingga mengakibatkan bayangan objek lama kelamaan akan jatuh di depan retina atau terjadinya miopia. ${ }^{19}$

Perilaku durasi penggunaan gadget yang berlebihan dapat menyebabkan penurunan tajam penglihatan yang disebabkan oleh stres yang terjadi. Stres pada otot akomodasi dapat terjadi pada saat seseorang berusaha untuk melihat objek berdimensi kecil dengan jarak dekat dalam periode yang lama. Otot-otot mata akan dipaksa bekerja secara terus menerus. Peningkatan asam laktat akan terjadi akibat ketegangan otot-otot pengakomodasi (otot-otot siliar) dan akan mengakibatkan terjadinya kelelahan mata. Stres pada retina dapat terjadi apabila terdapat kontras yang berlebih dalam lapang penglihatan durasi yang panjang. ${ }^{20}$

\section{SIMPULAN}

Tidak terdapat hubungan antara posisi penggunaan gadget dan frekuensi penggunaan gadget terhadap miopia pada anak sekolah dasar kelas 6. Terdapat hubungan antara jarak penggunaan gadget terhadap miopia pada anak sekolah dasar kelas 6 .

\section{KONFLIK KEPENTINGAN}

Penulis menyatakan tidak terdapat konflik kepentingan terkait publikasi dari artikel ini.

\section{PENDANAAN}

Penelitian ini tidak mendapatkan pendanaan baik dari pemerintah maupun sector swasta lainnya.

\section{ETIKA DALAM PENELITIAN}

Penelitian ini telah disetujui oleh Komite Etik Fakultas Kedokteran, Universitas Udayana/RSUP Sanglah Denpasar dengan nomer referensi 2325/ UN14.2.2.VII.14/LP/2019.

\section{DAFTAR PUSTAKA}

1. National Eye Institute. Facts about myopia. 2016. [sumber online]. Diakses tanggal: 28 Mei 2017. Diakses dari: https://nei.nih.gov/health/errors/myopia.

2. World Health Organization (WHO). 2010. The Impact Of Myopia and High Myopia. World Health Organization. 2010. h. 1-40.

3. Elisa Y. Latar belakang miopia. 2015. [sumber online]. Diakses tanggal: 28 Mei 2017. Diakses dari: http://eprints. undip.ac.id/46853/2/Yustina_Elisa_22010111130122_Lap. KTI_Bab1.pdf.

4. Hayatillah A. Prevalensi miopia dan faktor-faktor yang mempengaruhinya pada mahasiswa Program Studi Pendidikan Dokter UIN Syarif Hidayatullah Jakarta tahun 2011. 2011. [sumber online]. Diakses tanggal: 28 Mei 2017. Diakses dari: http://repository.uinjkt.ac.id/dspace/ bitstream/123456789/25481 / / Aemsina\%20Hayatillah\% 20-\%20fkik\%20.pdf.

5. Goldschmidt E, Jacobsen N. Genetic and environmental effects on myopia development and progression. Eye. 2013;28(2):126-33

6. Lougheed T. Myopia: the evidence for environmental factors. Environmental Health Perspectives. 2014; 122(1):12-9.

7. Suherman. Buku Saku Perkembangan Anak. EGC. 2012. h.72-9.

8. Bawelle CFN, Lintong F, Rumampuk J. Hubungan penggunaan smartphone dengan fungsi penglihatan pada mahasiswa Kedokteran Universitas Sam Ratulangi Manado angkatan 2016. Jurnal e-Biomedik. 2016;4(2):1-6.

9. Wolfson P. Mobile devices use causing nearsightedness in children. 2014. [sumber online]. Diakses tanggal: 28 Mei 2017. Diakses dari: http://wtop.com/news/2014/02/ mobile-device-use-causing-nearsightedness-in-children/.

10. Rudhiati F, Apriany D, Hardianti N. Hubungan durasi bermain video game dengan ketajaman penglihatan anak usia sekolah. Jurnal Skolastik Keperawatan. 2015;1(2):12-7.

11. Ernawati W. Pengaruh penggunaan gadget terhadap penurunan tajam penglihatan pada anak usia sekolah (612 tahun) di SD Muhammadiyah 2 Pontianak Selatan. Proners. 2015;3(1):21-7.

12. Suangga A, Ropi H, Mardhiyah A. Hubungan aktivitas bermain video games dengan school myopia pada siswasiswi SD Asy Syifa 1 Bandung. Jurnal Unpad. 2012;1(1): $1-15$.

13. Zulfiani E. Hubungan durasi waktu, posisi, dan jarak pandang penggunaan gadget dengan miopia pada siswa kelas I sekolah dasar di wilayah kerja Kecamatan Samarinda Ulu Tahun 2018. 2018. [sumber online]. Diakses tanggal: 10 Juli 2017. Diakses dari: https://dspace.umkt.ac.id/bitstream/ handle/463.2017/652/NP\%20KESMAS\%202018\%20 ELI\%20ZULFIANI.pdf?sequence=1\&isAllowed=y. 
14. Arianti MP. Hubungan antara riwayat miopia di keluarga dan lama aktivitas jarak dekat dengan miopia pada mahasiswa PSPD Untan Angkatan 2010-2012. 2013. [sumber online]. Diakses dari: http://jurnal.untan.ac.id/index. php/jfk/article/view/3768/3770. Diakses tanggal: 28 Mei 2017.

15. Handriani R, Mahawati E. Pengaruh unsafe action penggunaan gadget terhadap ketajaman penglihatan siswa Sekolah Dasar Islam Tunas Harapan Semarang Tahun 2016. 2016. [sumber online]. Diakses tanggal: 10 Juli 2017. Diakses dari: http://eprints.dinus.ac.id/19107/2/ jurnal_18462.pdf.

16. Chellavel GK, Paul AV, Kokila K, Bharath KS. A study on prevalence of myopia and its associated factors in school children of Salem, Tamil Nadu. IJCMPH. 2017; 4(8):24-9.

17. Purwanto S. Faktor determinan yang berhubungan dengan kejadian miopia. Jurnal Ilmu Kesehatan Masyarakat. 2010;1(3):162-69.
18. Trisna IF. Hubungan lama penggunaan dan jarak pandang gadget dengan ketajaman penglihatan pada anak sekolah dasar kelas 2 dan 3 di SDN 027 Kota Samarinda. 2017. [sumber online]. Diakses tanggal: 10 Juli 2017. Diakses dari: https://dspace.umkt.ac.id/bitstream/handle/463.2017/192/ SKRIPSI.pdf? sequence $=$ 2\&isAllowed $=y$.

19. Triharyo I, Gunawan W, Suhardjo. Pertambahan miopia pada anak sekolah dasar daerah perkotaan dan pedesaan di Daerah Istimewa Yogyakarta. Universitas Gadjah Mada. 2008. h. 249-51.

20. Ilyas S. Ilmu Penyakit Mata. FK UI. 2010. h. 521-9.

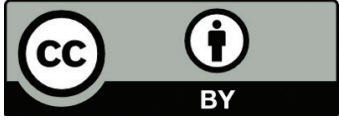

This work is licensed under a Creative Commons Attribution 